island 30 miles off Mazatlan. When the two-story wireless building collapsed, the chief wireless operator and his assistant were killed. The third, which did some damage, also occurred on December 4 from a focus having an epicentre near latitude $33.9^{\circ} \mathrm{N}$., longitude $116 \cdot 4^{\circ} \mathrm{W}$,, in southern California. The strongest effects were stated locally to have been in the desert between the towns of Indio and TwentyNine Palms, and the shock would undoubtedly have done more damage had it occurred nearer to a centre of population.

The other strong earthquakes during the quarter had dates and epicentres as follow : October 1, near Guerrero, coast of Mexico; October 15, north of Falkland Islands; October 18, between Crete and Rhodes; October 21, off west coast of Nicaragua ; October 21, near Solomon Islands; October 28, near coest of Honshu, Japan ; November 1, Kamchatka; November 3, Loyalty Islands; November 19, near coast of western Costa Rica; November 21, Queen Charlotte Islands ; November 26, New Guinea; December 5, south-east of New Zealand.

Of the minor shocks, an earth tremor of unknown origin was felt in Cheshire about 7.45 a.m. on October 4, one at Lyons (France) on October 20, one at Oporto (Portugal) on November 18, several in the latter half of November in the canton of Zurich (Switzerland), and others elsewhere.

None of this seismic activity can be said to have occurred in unexpected places since earthquakes have happened in the above regions previously. Seismo. gram readings have been received from the central stations of the Jesuit Seismological Association, United States; Strasbourg, France; United States Coast and Geodetic Survey; and individual stations at Aberdeen, Beograd, Cleveland (Ohio), De Bilt, Durham, Kew, Stuttgart, Toledo, Uccle and Zurich.

\section{NEW BELGIAN INSTITUTE FOR SCIENTIFIC RESEARCH IN CENTRAL AFRICA}

$\mathrm{T}$

WE Instity pour la Recherche Scientifique on Afriqu Centrale (I.R.S.A.C.), which was created on Jyy 1, 1947, at Leopoldville, is a public corporation that is to say, it is sponsored by the Governmgat but ruled by a board of twenty-five administrators. At the beginning of 1948, the Institute was endowed with 200 million Belgian francs $(£ 1,129,000)$, to be used for the erection of buildings, and another 200 million franes to be kept in Govern. mont bonds. This initial endowment will be supple. mented with annual subsidies, the minimum at present being 25 million francs $(£ 141,240)$.

The purpose of the Institute is the fundamental study of human, zoological and botanical environment in the tropics. Several research centres will be erected in the Congo during the next two years. The main one will probably be on the high plateau between Lake Kivu and Lake Tanganyika, south of Costermansville, where a team is now in the field, searching for a suitable site for a high-altitude astronomical observatory. This main station will house a laboratory of vulcanology, seismology and ionospheric measurements, and a department of experimental biology. Early this year a research centre devoted to hydrobiological studies will be opened at Uvira, on the northern shore of Lake Tanganyika. Another centre, for researches on physical and social anthropology, will be started, before the end of the year, at Astrida in the Ruanda, east of the Congo. A fourth station will be erected in the Province of Equator, in the low central forest, and dedicated to studies on climatology, hydrobiology, anthropology, nutrition, botany, etc.

The Belgian Congo offers unusually favourable conditions for the study of tropical environment with its wide variety of altitudes and an exceptionally good road system. The Institute will provide fellowships and subsidies to the scientific workers established in the Congo. Its aim is to co-ordinate and inspire the various scientific institutions and services there. It will have its own scientific and technical staff and will act as an information agency for men of science visiting the Congo and provide them with material help and various exploration and research facilities. Work tables will be kept at the disposal of Belgian and foreign institutions in the different centres, and a library, by far the largest one yet available in Central Africa, will be assembled at the headquarters.

The board of administrators, under the presidency of Prof. E. De Bruyne, of the University of Ghent, who was formerly Minister of Colonies in the Belgian Government, is composed of representatives of all branches of science. All of them are Belgian, except for three: Dr. E. B. Worthington, scientific adviser to the High Commissioner for East Africa in Nairobi; Dr. Harlow Shapley, director of the Harvard College Observatory; and M. A. Chevalier, professor of Colonial agriculture in the Musée Nationale d'Histoire Naturelle, Paris.

The director of the Institute, Dr. Louis van den Berghe, professor at the Institute of Tropical Medicine, Antwerp, is already established in the Belgian Congo. The present address is I.R.S.A.C., B.P. 217, Costermansville, Belgian Congo. M. J.-P. Harroy, former secretary of the Institut des Pares Nationaux du Congo Belge, is the secretary-general of the administrative services in Brussels at 42 rue Montoyer. No scientific journal will be maintained by the Institute; but a scientific report on general subjects, including abstracts of the papers published elsewhere by the members and guests, will appear annually. A first report, for 1948 , will be published by the middle of 1949 .

\section{2 $23 / 3$ \\ FORTHCOMING EVENTS}

(Meeting marked with an asterisk * is open to the public)

Monday, April 4

SOCIETY OF Chagical INDUSTRY, LONDON SECTION (joint meeting with the LONDON A NPA. E. COUNTIES SECTION of the ROYAL INSTITUTR with the LONDON A NP.E. COUNTIES SECTION of the ROYAL INSTTPTTE Keppel Strpet, (0. don, W.C.1), at 6.30 p.m.-Dr. A. Forster : "Recent Keppel Stypet, (0.0 don, W.C.1), at 6.30 p.m.-Dr. A. Forster : "Recent
Developme tits in Explosives".

IISTTTUTION OF ELROTRICAL ENGINRERS, LONDON STUDENTS' SEd ros (at Savoy Place, Victoria Embankment, London, W.C.2), at 7 p.m.-Mr. T. Graeme N. Haldane: "Future Methods of Power Generation, and other Problems" (Presidential Address).

Tuesday, April 5 ROYAL ANTHROPOLOGICAI INSTTTUTE (at 21 Bedford Square, Lon-
don, W.C.1), at 5 p.m.-Dr. Fernando Henriques: "West Indian Family Organisation".

INSTIXUTION OF ELECTRIOAC ENGINEERS, RUGBY SUB-CANTRE (at the Electricity Showrooms, Rugby), at 6.30 p.m.-Mr. C. A. Cameron Brown and Mr. E. W. Golding: "The Application of Electricity to Agriculture".

MANohEster GeOgraphical Society (in the Geographical Hall, St. Mary's Parsonage, Manchester), at 6.30 p.m.-Mr. C. A. J. Barrington: "Growing Trees". 